Tarih Kültür ve Sanat Araştırmaları Dergisi

Revue des Recherches en Histoire Culture et Art

مجلة البحوث التاريخية والثقافية والفنية
Vol. 6, No. 4, September 2017

Copyright (C) Karabuk University

http://kutaksam.karabuk.edu.tr

\title{
DOI: 10.7596/taksad.v6i4.1157
}

Citation: Shayakhmetova, L., Shayakhmetova, L., Ashrapova, A., \& Zhuravleva, Y. (2017). Using Songs in Developing Intercultural Competence. Journal of History Culture and Art Research, 6(4), 639-646. doi:http://dx.doi.org/10.7596/taksad.v6i4.1157

\section{Using Songs in Developing Intercultural Competence}

\author{
Liliia Shayakhmetova ${ }^{1}$, Leysan Shayakhmetova ${ }^{2}$, \\ Alsu Ashrapova ${ }^{3}$, Yevgeniya Zhuravleva ${ }^{4}$,
}

\begin{abstract}
Songs in teaching English are not used to the full extent. To confirm this, we created a set of exercises based on the use of songs to form socio-cultural and regional knowledge, to familiarize students with the culture and way of life of Great Britain, to gain a deeper understanding of the representatives of this linguistic cultural community. The next step was carrying out a survey on revealing the effectiveness of using songs in EFL class, more precisely their effect on the developing of intercultural competence. Following methods were used to conduct the survey: the questionnaire of teachers and students, to determine the role of English songs in the developing of intercultural competence; the analysis of English language course books to determine the presence of songs focusing on their cultural significance; Life in the UK Test, a test to check the knowledge of the history and culture of Britain. The results of the research showed the expediency of using song to develop intercultural competence. Moreover, use of songs aroused interest among students; they expressed the opinion that lyrics have a much deeper meaning and varied information than they thought before using them in English classes. They expressed a desire to continue using songs during classes in keeping with this approach.
\end{abstract}

Keywords: Song lyrics, Intercultural competences, Lingua culture, English language teaching, EFL class.

\footnotetext{
${ }^{1}$ Kazan Federal University, Leo Tolstoy Institute of Philology and Intercultural Communication. E-mail: corbita@list.ru

${ }^{2}$ Kazan Federal University, Leo Tolstoy Institute of Philology and Intercultural Communication. E-mail: habirshah@mail.ru

${ }^{3}$ Kazan Federal University, Leo Tolstoy Institute of Philology and Intercultural Communication. E-mail: chudosun@list.ru

4 L.N. Gumilyov Eurasian National University, Head of Theoretical and Applied Linguistics. E-mail: zhuravleva_ea@enu.kz
} 


\section{Introduction}

\section{Intercultural competence}

According to Messner and Schäfer (2012), intercultural competence is the ability to communicate effectively and appropriately with people of other cultures. Russian Federal State Educational Standard states, intercultural competence is introduction to the culture, traditions, realities of the country which language we learn in the framework of topics, spheres and situations of communication that corresponds to the experience, interests, psychological characteristics of students; the ability to represent your country, its culture in the context of intercultural communication.

Zamaletdinov, Zamaletdinova, Nurmukhametova, Sattarova (2014) argue that language and culture should be combined. A linguistic and cultural analysis of the language makes it possible to understand perception, imagination, emotions of people, and to study the system of thinking of native speakers. Byram (1991), offer a four-dimensional approach. These four dimensions include language learning, language awareness, cultural awareness, and cultural experience. He emphasizes on non-linguistic dimensions of culture, where students are taught to look at cultural differences from two perspectives - their native culture and foreign language culture. The main goal is to transform the monocultural understanding of the world into an intercultural one.

Kramsch (1993) offers the concept of "sphere of interculturality". Through this sphere, students will be able to understand the differences in culture and how these differences can affect intercultural communication. Moreover, an important feature of the "sphere of interculturality" is the development of intercultural competence, which implies the preservation of the cultural norms of one's own nation by accepting the cultural norms of another people, as well as the awareness of existing cultural differences and the ability to use this knowledge for effective intercultural communication. The ideas above lead to the conclusion that the formation of a socio-cultural knowledge or developing of intercultural competence is especially critical for the mastery of a foreign language.

\section{Songs in English language learning}

Songs in teaching English are not used to the full extent. Although Murphey (1992), Jalongo and Bromley (1984), Martin (1983), Mitchell (1983), having collected and analyzed a corpus of popular English songs, concluded that songs were useful and significant tool for improving the quality of teaching foreign languages, they identified using songs in only five aspects (listening, grammar, pronunciation, vocabulary, fun and motivation). Songs as a tool of 
developing sociocultural and linguistic-cultural knowledge were not reflected in the EFL learning.

Further Shen (2009), Schoepp (2001), Griffee (2010), Eken (1996, cited in Shoepp 2001), Cheung (2001) support this idea and claim that the use of songs in language acquisition helps to learn vocabulary and grammar, improve spelling and listening skills. As reported by them, songs can be used as a tool for teaching English and contain great benefits in three aspects: affective, cognitive and linguistic.

In terms of affective aspect, songs have a positive impact on learning. They provide a relaxed atmosphere in the classroom; activate discussion of attitudes to something or someone; reduce anxiety during the learning process; encourage creativity and imagination; stimulate extensive and intensive listening; bring variety and fun to the learning process.

On the second aspect, songs can be used to automate of certain processes of cognitive functions. Automatism, as a rule, develops through the practice of various skills. Therefore, repeated songs listening and frequent repetition of song lines can contribute to an automatism development.

From the linguistic point of view, songs contain phrases of spoken English, slang and idioms. That is, a teacher can give examples of real language use or encourage students to independently search for word expressions and collocations. In this manner, they state songs develop the linguistic skills of reading, writing, speaking and listening.

However, Jolly (1975), Candlin (1992), Engh (2013), Yarmakeev (2016), Shaiakhmetova, Shayakhmetova, Ashrapova, Mukharlyamova, Mukhametzyanova, (2016) emphasize one more benefit - the cultural exposure of the song. They argue songs help to look deeper into the cultural heritage of different societies, better understand the values of people whose language we learn. At the same time, they say that a lack of empirically based research exists on the topic of the cultural significance of songs.

The relevance of the development of intercultural competence among students through using songs is determined by the absence of a special technique and theoretical perspective in this field, including procedure and a set of exercises.

\section{Method}

A total of 130 students aged 19-20 years old (all of them first-year students of the Institute of Philology and Intercultural Communication of the KFU) were included in the study.

Following methods were used in the research: the questionnaire of teachers and students, to determine the role of English songs in the developing of intercultural competence; the 
analysis of English language books for the presence of songs focusing on their cultural significance; Life in the UK Test, a test to check the knowledge of the history and culture of Britain.

Teacher questionnaire, a survey consisting of 12 questions, was aimed at collecting information on the use of English song lyrics in English teaching. Results gave information on the frequency of working with English songs; pedagogical material for the use of songs; various ways of using songs for English teaching; beneficial aspects of songs as a language teaching tool.

Student questionnaire, a form based on 9 questions, was aimed at gathering information about students attitude to use of songs in English classes; song-using techniques introduced by their English teachers; what English songs they would prefer to work with during the classes.

Life in the UK Test. The test checks whether a test taker has sufficient knowledge of the socio-cultural life of the Britain and a sufficient level of English proficiency. It consists of 24 questions covering topics such as British values, history, customs and traditions, everyday life of the British.

\section{Procedure}

The study contained three stages. The first stage covered analysis of theoretical material on the research problem; questioning of teachers and students; selection of songs based on the content of socio-cultural and linguistic information; creation of exercises for using songs for the developing intercultural competence; testing knowledge of students in the field of culture and history of Great Britain.

At the second stage, the experimental group carried out training based on the set of exercises for the song-based formation of intercultural competence by using songs. Experimental training lasted for one year, with lessons twice a week. The training was incorporated in the curriculum and took 15-20 minutes of the first class (pre- and while-activities) and 20 minutes of the second class (post-activity: project work).

The third stage included the final control test and the statistical processing of the experimental data, accompanied by their interpretation.

The model of training in the experimental group was based on a study guide. The study guide contains eighteen topics, the basis information about British institutions and everyday life. In each topic, there are from five to six songs plus pre-, while-, post- activities. Pre-activity phase involves focusing on material, activating prior general knowledge, motivating the 
learners for the activity, preparing for the language, familiarization with the format of the target text. While-activity phase contains performing the task, doing communicative and/or meaningful drill, using given material for communicative and creative purposes. Post-activity phase encompasses reflecting on the results, re-visiting material, further tasks for classroom or independent studies (integrated with teaching communicative skills). Tasks are presented in various forms (quotes, true-false tests, filling the gap and other exercises, information boxes, project works, etc). Each lyric is supported by glossary and some of them include song facts. Consequently all of them together help learners consolidate their learning of British life and vocabulary and widen their knowledge in that respect.

As an example, we can introduce the topic of British food. In pre-activity a teacher performs two quotations of famous foreigners "You cannot trust people who cook as badly as that" by former French President Jacques Chirac and “On the Continent people have good food, in England people have good table manners” by satirist George Meeks; and asks students to comment these statements. In while-activity the song Food, Glorious Food by cast of Oliver is played and exercises on understanding and vocabulary are done. In post-activity informationbox of eating habits and attitudes of the British are given, extra songs are suggested to better realize their attitudes to food and students are tasked to make project work on the following topics: a typical British food, popular dishes in modern London, meal times, eating etiquette, eating out. Altogether it creates a credible image of British cuisine that is incomprehensible and not accepted by foreigners, but beloved by the British themselves.

\section{Results}

The results of the questionnaire showed a positive attitude both of the students (100\%) and the teachers (83\%) to the use of songs in English classes.

$76 \%$ of the teachers find it beneficial to use songs as additional material for the development of phonetic, lexical, grammatical and communicative skills, for the acquaintance with regional information (culture and history of the country that language is learnt), for fostering a tolerant, positive attitude to other cultures, for relaxation and increasing motivation for learning English.

However, when selecting songs, the teachers do not pay attention to the availability of linguistic and socio-cultural information in lyrics. Although they believe songs are valuable tool for language development and acquaintance with the culture, customs, psychology of native speakers, $67 \%$ of the teachers hardly use them in English classes. 
$72 \%$ of students stated that they did not work with lyrics in high school. Among the rest $28 \%$ of students $8 \%$ of learners mainly listened to songs and translated them, 14\% listened, did some exercises and translated, $6 \%$ adding to previous activities performed a creative task. No student has confirmed that a teacher gave some background information of songs or introduced socio-cultural information of them.

The analysis of 12 books on the English language (Pre-Intermediate and Intermediate level) for the presence of songs containing socio-cultural information revealed small amount of using exercises based on songs. Song lyrics are assigned an insignificant role in the content of textbooks. The most well-developed exercises based on songs are in New English File Student's book, $15 \%$ of all texts are lyrics with tasks on reading, speaking, listening and grammar. However, not a single textbook pays attention to developing socio-cultural or linguistic knowledge. The textbooks include mostly popular songs with a clear pronunciation and a shallow meaning, even the songs with linguistic and regional information do not paid attention to that and no exercises are offered for their elaboration.

The results of the initial test checking the knowledge of the history and culture of Britain revealed that the average level of socio-cultural and linguistic-cultural knowledge among the students of the experimental group was $38.83 \%$ and $39.03 \%$ in the control group. A final test was performed after the training with the usage of songs in experimental group. The analysis of the data showed that the average level of socio-cultural and linguistic knowledge among students of the experimental group was $55.89 \%$ and in the control group $42.23 \%$. The average growth rate of the level of socio-cultural and linguistic knowledge in the experimental group estimated $17.06 \%$, in the control group this change was only $3.2 \%$. In a comparative analysis of the data, we found out that there is statistically significant difference between the two groups of students $(\mathrm{p} \leq 0,01)$.

\section{Discussion}

Thus, the analysis of the textbooks and questionnaires of teachers and students led to the conclusion that using songs in teaching English is episodic; it does not allow developing communicative skills; it does not contribute to the development of socio-cultural and linguistic knowledge; it does not promote the development of intercultural competence. This may be due to the lack of knowledge of empirical literature on using songs, as well as the insufficient number and quality of songs offered in the English textbooks. As song lyrics are assigned an insignificant role in the content of textbooks. 
Relying on the results we assumed that developing the model of training in the experimental group based on a study guide including 90 songs with socio-cultural information would be beneficial. According to Engh (2013), every song has under song (inner meaning), some moments unsaid or unexplained that authors assume the listeners know as their background knowledge, but non-native speakers lack this. Therefore the aim of this guide is to fill the gap, so that students will be able to look behind the details that every British knows, get an insight into the British approach to life in general.

As a result, the data from the final test showed the effectiveness of the proposed method of using songs as means of developing the intercultural competence of junior students. In addition, these results confirm the methodological expediency of using the developed set of exercises.

\section{Conclusion}

To summarize, it should be noted that the results of the experimental training confirmed the expediency of using song in development of intercultural competence. Moreover, using songs aroused interest among students; they expressed the opinion that lyrics have a much deeper meaning and varied information than they thought before using them in English classes. They expressed a desire to continue using songs during classes in keeping with this approach.

\section{Acknowledgement}

The work is performed according to the Russian Government Program of Competitive Growth of Kazan Federal University.

\section{References}

Byram, M. (1991). Teaching Culture and Language: Towards an Integrated Model. In D. Buttjes and M. Byram (eds.), Mediating Languages and Culture (pp. 17-30). Clevedon: Multilingual Matters.

Candlin, C. (1992). Preface in Griffee, D. Songs in Action: Classroom Techniques and Resources (ix-x). New York: Prentice Hall. 
Cheung, C. K. (1998). The Use of Popular Culture in Teaching Civics Education Unpublished INSTEP Report. Hong Kong: Government Printer.

Engh, D. (2013). Why Use Music in English Language Learning? A Survey of the Literature. English Language Teaching, 6(2), 113-127.

Federal State Educational Standard (2017). Retrieved March 22, 2017, from http://fgosvo.ru/news/4/1376.

Griffee, D. (1992). Songs in Action: Classroom Techniques and Resources (ix-x). New York: Prentice Hall.

Griffee, D. (2010). Personal communication with the author. New York: Prentice Hall.

Jalongo, M. \& Bromley, K. (1984). Developing linguistic competence through song. Reading Teacher, 37(9), 840-845.

Jolly, Y. (1975). The use of songs in teaching foreign languages. Modern Language Journal, 59(1), 11-14.

Martin, M. (1983). Success! Teaching spelling with music. Academic Therapy, 18(4), 505506.

Messner, W. \& Schäfer, N. (2012) The ICCA Facilitator's Manual. Intercultural Communication and Collaboration Appraisal. London: GloBus Research.

Mitchell, M. (1983). Aerobic ESL: Variations on a total physical response theme. TESL Reporter, 16, 23-27.

Murphey, T. (1992). Music and song. Oxford, England: Oxford University Press.

Shaiakhmetova, L.; Shayakhmetova, L.; Ashrapova, A.; Mukharlyamova, L. \& Mukhametzyanova, L. (2016) The developing social and cultural competences through allusions (by song lyrics of Pink and Lady Gaga). Modern Journal of Language Teaching Methods, Special Issue, 81-85.

Shen, C. (2009). Using English songs: An enjoyable and effective approach to ELT. English Language Teaching, 2(1), 88-94. Retrieved June 10, 2016, from www.ccsenet.org/journal.html

Shoepp, K. (2001). Reason for using songs in the ESL/EFL classroom. The Internet TESL Journal, 7(2). Retrieved July 15, 2016, from http://iteslj.org/Articles/Schoepp-Songs.html

Yarmakeev, I. E.; Pimenova, T. S.; Abdrafikova, A. R. \& Syunina, A. S. (2016). Folk songs do magic in teaching speech and grammar patterns in EFL class. Journal of Language and Literature, 7(1), 235-240.

Zamaletdinov, R. R.; Zamaletdinova, G. F.; Nurmukhametova, R. S. \& Sattarova, M. R. (2014). The lexicon and its reflection in the inner world of the individual (on the basis of the Tatar language). Journal of Language and Literature, 5(4), 333-335. 